\author{
S.V. Karpov, A.S. Dzhalmukhanova, D.A. Chernyayev, V.P. Lodygina, \\ V.V. Komratova, G.V. Malkov, E.R. Badamshina \\ Institute of Problems of Chemical Physics of RAS, Chernogolovka, Moscow region, Russia \\ (E-mail: svkarpov@icp.ac.ru)
}

\title{
Investigation of isophorone diisocyanate oligoisocyanurate effect on water dispersible polyurethane properties
}

\begin{abstract}
Oligoisocyanurates (OIC) are the products of various diisocyanates cyclotrimerization reaction, with their functionality being more than three (potential crosslinking agents). They are applicable in chemical polymer industry as an additive to diisocyanates for polyurethane coatings obtaining with various properties, as well as an isocyanate-containing component on its own for polyurethane synthesis. The OIC-based polymers possess a number of unique properties, e.g. improved thermal stability, fire resistance, UV resistance, also they are not expected to undergo hydrolysis. We studied the effect of isophorone diisocyanate oligoisocyanurate content on hydrodynamic, thermo-mechanical and thermal properties of resulting water dispersible polyurethanes. Samples of water dispersible polyurethanes containing isophorone diisocyanate (IPDI), poly (butylene adipate) (PBA) and 2,2-dimethylolpropionic acid (DMPA) were prepared following acetone method for this purpose, with IPDI OIC amount being 10-30 wt.\% per pure IPDI. IPDI OIC was partially blocked with morpholine to exclude crosslinking in WDPU synthesis. Dynamic mechanical analysis (DMA), differential scanning calorimetry (DSC), and dynamic light scattering (DLS) were used to characterize the polymers obtained. It was established that oligoisocyanurates improve the characteristics of both water dispersible polyurethanes and their polymer films. Moreover, oligoisocyanurates prevent polyurethane coatings crystallization due to its branched structure, which without a doubt will affect their performance positively.
\end{abstract}

Keywords: polyurethane, water dispersible polyurethane, isophorone diisocyanate, 2,2-bis(hydroxymethyl)propionic acid, poly(butylene adipate), isophorone diisocyanate oligoisocyanurate, dynamic light scattering, dynamic mechanical analysis

\section{Introduction}

Polyurethane is one of the most demanded polymers in many industries nowadays. It stands out by a sufficiently large operating temperature range and high strength characteristics. The application of polyurethanes varies from sheets for making surfaces of spindles, rollers, wheels to base for paints, varnishes and binders for important composites.

Water-based polyurethane dispersions, namely one- $(1 \mathrm{~K})$ and two-component $(2 \mathrm{~K})$ waterborne polyurethane compositions are reported to be a relatively new eco-friendly type of polyurethane coating compounds. Their application tends to increase in the painting of wood, plastic, metals and other materials [1-3]. Despite the high quality, unique durability and environmental benefits of $2 \mathrm{~K}$ waterborne polyurethanes, they have significant disadvantages related to the limited viability and relative toxicity of the isocyanate component. $1 \mathrm{~K}$ waterborne polyurethane based on prepolymers of physical drying or self-crosslinking film forming agents appeared to be much more technologically advanced and safe.

The preparation of a prepolymer is the main stage in the synthesis of $1 \mathrm{~K}$ water dispersible polyurethanes (WDPU). Bifunctional isocyanates, e.g. isophorone diisocyanate (IPDI) [4], hexamethylene diisocyanate (HDI) [5], toluene diisocyanate (TDI) [6] etc., polyols of various molecular weight [7], as well as hydroxylor amino-terminated low molecular weight bifunctional chain extenders [8] are used for that purpose. It is also necessary to reach the water dispersibility for the resulting prepolymer - to that end, a hydrophilic agent is introduced into the composition. Salt of 2,2-bis(hydroxymethyl)propionic acid (DMPA) is one of the most commonly used hydrophilic agents $[9,10]$.

Oligoisocyanurates (OIC), which are the products of the cyclotrimerization reaction of various diisocyanates $[11,12]$, are possible to use in the synthesis of WDPU. OIC found application in chemical industry as an additive to diisocyanates in order to obtain polyurethane coatings with refined properties [13], as well as an isocyanate-containing component on its own in the synthesis of polyurethane and hybrid composites [14, 15], and aerogels. It was reported $[16,17]$ that polyurethanes obtained using OIC had high thermal resistance and fireproof, also resistance to UV and hydrolysis. Furthermore, OIC can be modified with various low molecular 
weight compounds containing groups reactive to isocyanate ones. The above-mentioned fact also allows vary WDPU properties over a wide range.

After having reviewed the available sources, a limited number of works dedicated to WDPU synthesis using HDI- [13, 18-20] and IPDI-based [3, 15] OIC were found. Moreover, the effect of the HDI OIC content on WDPU properties was studied thoroughly in the first articles, while only basic opportunity to obtain WDPU was shown in the latter ones.

In our opinion, the use of IPDI-based OIC in the WDPU synthesis seems preferable due to IPDI containing aliphatic and cycloaliphatic isocyanate groups of different reactivity. The reactivity of isocyanate groups can vary widely $[21,22]$ depending on the synthesis conditions. This provides the ability to control the prepolymer structure and hence the properties of the final product. Furthermore, IPDI-based OIC are completely soluble even at NCO conversion of $\sim 73 \%$ as noted in the [3]. In contrast, the critical gelation conversion of HDI cyclotrimerization reaction products is only $50 \%$. This experimental fact allows changing WDPU properties to a larger extent due to the various degree of OIC modification.

There is no doubt that $1 \mathrm{~K}$ WDPU properties with IPDI-based OIC depend on the isocyanurate content in the system, the degree of modification and the IPDI NCO groups conversion in OIC.

The objective of this study thereby is to investigate the effect of IPDI-based OIC content in WDPU on hydrodynamic, thermal and thermo-mechanical properties of resulting products.

\section{Experimental}

\section{Materials and instruments}

IPDI $(98 \%)$ was purchased from Sigma-Aldrich and then purified by vacuum distillation at $\mathrm{T}=90{ }^{\circ} \mathrm{C}$ $(10 \mathrm{mmHg}) ; \mathrm{T}_{\mathrm{b}}=158-159^{\circ} \mathrm{C} ; \mathrm{d}^{25}=1,049 \mathrm{~g} / \mathrm{cm}^{3} ; \mathrm{n}_{\mathrm{D}}{ }^{20}=1,4840$.

2,2-bis(hydroxymethyl)propionic acid (98\%) (DMPA) was purchased from Sigma-Aldrich, 1,2-diaminopropane (99\%) (DAP) and N,N,N-triethylamine (99\%) (TEA) were purchased from Acros Organics. These chemicals were used without further purification.

Poly(butylene adipate) (PBA) was purchased from Aldrich; the content of hydroxyl groups is $1.7 \mathrm{wt} . \%$ $\left(\mathrm{M}_{\mathrm{n}} \sim 2000\right)$, determined by chemical method.

Acetone, morpholine (99 \%) and 1,4-butanediol (99\%) (BD) were purchased from Sigma-Aldrich. These chemicals were purified by standard method [23].

Catalysts: 1,4-diazobicyclo[2.2.2]octane (98\%) (DABCO), propylene oxide (98\%) (PO) and dibutyltin dilaurate $(95 \%)$ (DBTDL) were purchased from Aldrich and were used without further purification.

Synthesis of isophorone diisocyanate oligoisocyanurates

Polycyclotrimerization of IPDI was carried out in the mass in presence of DABCO $(0.4$ wt.\% $)+$ PO ( 2 wt. \%) catalytic system, $\mathrm{T}=60^{\circ} \mathrm{C}$. The reaction was controlled by FTIR spectroscopy using ALPHA spectrometer (Bruker, Germany) using $\mathrm{NaCl}$ cuvettes by a decrease in absorption line intensity $\left(v=2270 \mathrm{~cm}^{-1}\right)$ which corresponds to NCO asymmetric stretching vibrations.

IPDI-based OIC with NCO conversion of $20 \%$ for the WDPU synthesis was partially blocked with morpholine, $0.31 \mathrm{~g}$ of morpholine per $1 \mathrm{~g}$ of IPDI OIC. The content of aliphatic and cycloaliphatic NCO groups in the IPDI OIC determined by the method described in [24] was $33 \%$ and $67 \%$, respectively.

Synthesis of waterborne polyurethanes

Synthesis of WDPU-10 containing $10 \mathrm{wt} . \%$ of IPDI OIC (per pure IPDI) went as it follows. DMPA (1.20 g) and TEA $(0.90 \mathrm{~g})$ were put into a $250 \mathrm{~mL}$ flask with ground glass neck. A sample of PBA $(14.89 \mathrm{~g})$ and BD $(0.58 \mathrm{~g})$ were added to the flask and were dissolved with constant stirring and $\mathrm{T}=55^{\circ} \mathrm{C}$ after the obtained DMPA salt was dissolved in acetone (32 g), pre-drained on molecular sieves. Then, IPDI (10.00 g) and DBTDL $(0.06 \mathrm{~g})$ were added to the flask. The reaction of urethane formation was carried out for 3 hours with constant stirring and $\mathrm{T}=55^{\circ} \mathrm{C}$ and was controlled by carrying out the titrimetric analysis [25]. After the reaction being done, partially blocked IPDI OIC $(1.31 \mathrm{~g})$ dissolved in acetone $(5 \mathrm{~g})$ was added into the flask. The reaction was carried out for 30 minutes.

After the first stage, the reaction mass was allowed to cool to the room temperature. Then, a chain extension was performed, with PDA sample $(1.78 \mathrm{~g})$ dissolved in $93 \mathrm{~g}$ of distilled water added to the flask with intense stirring $\left(\left[\mathrm{NH}_{2}\right] /[\mathrm{NCO}]=1\right)$. The excess acetone was removed in vacuum. The solid content in the final product was $25 \%$. 
WDPU-20, WDPU-30 and OIC-free WDPU-0 were prepared by the described technique. The precise formulation of WDPUs obtained is reflected in Table 1. DMPA content in every sample was $4 \mathrm{wt} . \%$, first stage of synthesis was characterized with the reactive groups ratio $[\mathrm{NCO}] /[\mathrm{OH}]=2.0$.

Table 1

Composition of water dispersible polyurethanes

\begin{tabular}{|c|c|c|c|c|c|c|c|c|c|}
\hline Sample & DMPA, $\mathrm{g}$ & TEA, $\mathrm{g}$ & PBA, $\mathrm{g}$ & BD, $\mathrm{g}$ & IPDI, $\mathrm{g}$ & IPDI OIC, $\mathrm{g}$ & Blocking agent, $\mathrm{g}$ & PDA, $\mathrm{g}$ & PBA, wt.\% \\
\hline WDPU-0 & 1.16 & 0.87 & 14.89 & 0.58 & 10.00 & 0 & 0 & 1.80 & 50.8 \\
\hline WDPU-10 & 1.20 & 0.90 & 14.89 & 0.58 & 10.00 & 1.0 & 0.31 & 1.78 & 48.6 \\
\hline WDPU-20 & 1.25 & 0.94 & 14.89 & 0.58 & 10.00 & 2.0 & 0.62 & 1.75 & 46.5 \\
\hline WDPU-30 & 1.30 & 0.98 & 14.89 & 0.58 & 10.00 & 3.0 & 0.93 & 1.72 & 44.6 \\
\hline
\end{tabular}

\section{Researching methods}

The viscoelastic properties of WDPU samples were investigated by dynamic mechanical analysis (DMA) using a DMA $242 \mathrm{C}$ device (Netzsch-Gerätebau GmbH, Germany): uniaxial tension on film samples, working length of $10 \mathrm{~mm}$, width of $3 \mathrm{~mm}$, thickness of $\sim 0.2-0.3 \mathrm{~mm}$, continuous scanning, $\mathrm{T}=-170 \div+170{ }^{\circ} \mathrm{C}$, a speed of $2 \% \mathrm{~min}$, helium atmosphere. A sinusoidal oscillating force was applied to the samples, allowing one to develop strain amplitude of up to $30 \mu \mathrm{m}$ at fixed frequency of $1 \mathrm{~Hz}$. The temperatures of relaxation transitions were determined by the inflection points on the curves of the safe modulus ( $\left.E^{\prime}\right)$.

Thermal analysis of WDPU samples was carried out using a METTLER TOLEDO DSC822e differential scanning calorimeter with a heating rate of $20 \% \mathrm{~min}$.

The particle size distribution in WDPU dispersions was determined by dynamic light scattering at 25 and $60{ }^{\circ} \mathrm{C}$ using a Photocor Compact.

\section{Results and Discussion}

As shown in [3], polycyclotrimerization can be presented as follows:
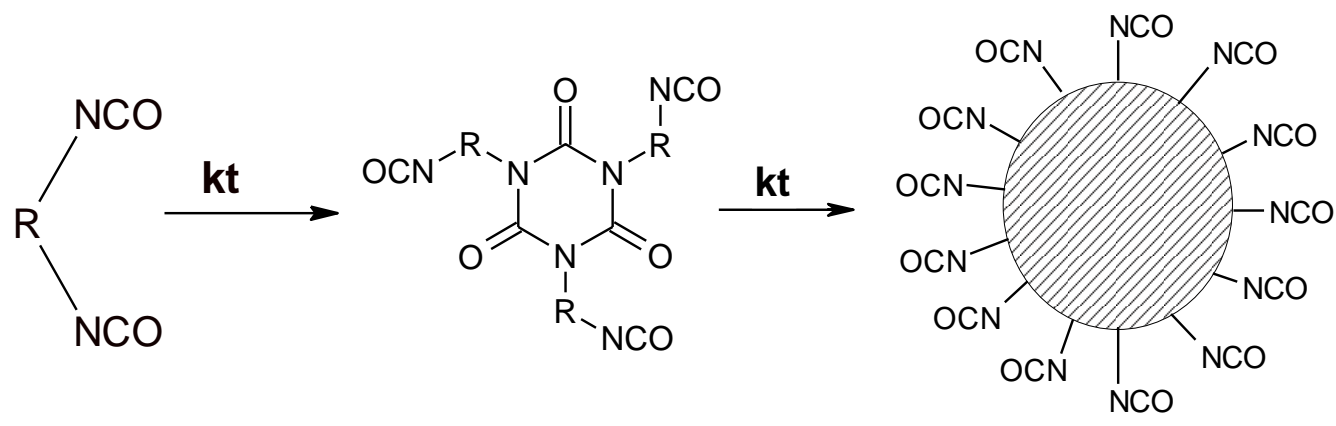

Trifunctional cycles are formed at the first stage during cyclotrimerization of diisocyanates. They form $\mathrm{n}$-mers and then a crosslinked polymer at subsequent reaction stages. As previously mentioned, the critical gelation conversion (CGC) in IPDI polycycloaddition is able to reach $73 \%$. However, using IPDI OIC in WDPU synthesis with NCO conversion not having yet reached CGC will result in obtaining crosslinked polymers highly likely. This deals with the obvious fact that different compounds that contain more than three functional groups, act as possible crosslinking agents. The part of polyfunctional compounds will obviously increase with the conversion of isocyanate groups. It is necessary to block partially the NCO groups of OIC to eliminate possible crosslinked structures formation during the WDPU synthesis. We determined [3] the critical gelation conversion in reaction between IPDI OIC and bifunctional compounds at different NCO group conversion values to define the minimum of NCO groups $\left(\omega_{\mathrm{NCO}}{ }^{\text {blocked }}\right)$ that are to be blocked. So, $\omega_{\mathrm{NCO}}{ }^{\text {blocked }}$ vs. NCO group conversion of IPDI OIC graph was obtained based on the data mentioned above (Fig. 1).

The minimum required value of $\omega_{\mathrm{NCO}}{ }^{\text {blocked }}$ increases with increasing of isocyanate groups conversion of IPDI OIC as expected.

However, polymer crosslinking and, accordingly, coating hardening after application means an open road to damp- and heat-proof coatings. Attention therefore should be paid to hydroxyl- and amine-terminated components with other functional groups as IPDI OIC blocking agents, e.g. double bonds (allyl alcohol, allylamine etc.). Self-crosslinking 1K WDPU can be obtained using that kind of IPDI OIC blocking agent. The degree of 
crosslinking for WDPU-based coatings will obviously be determined by functional groups content in the composition. Thus, there are two ways to control crosslinking. The first one is selecting highly converted IPDI OIC, and the second way is varying the IPDI OIC content in WDPU synthesis. We have investigated the second way in the context of this work.

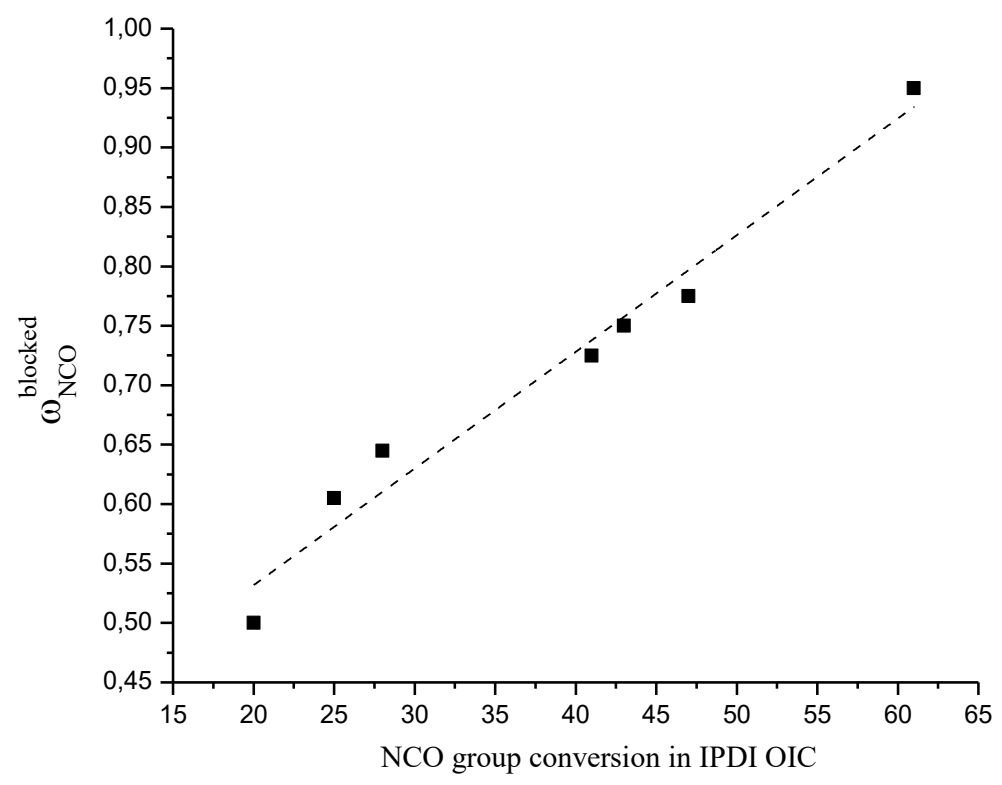

Figure 1. $\omega_{\mathrm{NCO}}{ }^{\text {blocked }}$ vs. NCO group conversion in IPDI OIC graph

To determine how IPDI OIC content influences waterborne polyurethanes, we prepared 3 samples containing IPDI OIC by weight (per free IPDI): $10 \%$ (WDPU-10), $20 \%$ (WDPU-20) and $30 \%$ (WDPU-30) (Table 1). OIC-free WDPU-0 obtained under similar conditions was used as a reference sample.

The size of dispersed particles and their distribution in dispersion medium is one of the main characteristics of any colloidal solution. Dynamic light scattering of all obtained dispersions was carried out to establish the IPDI OIC content impact in WDPU on their hydrodynamic characteristics. Table 2 and Figure 2 show results of the analysis.

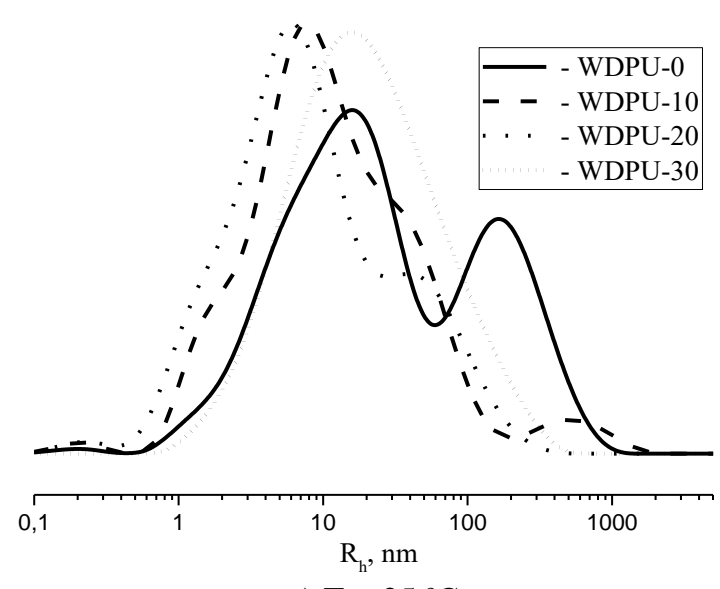

a) $\mathrm{T}=25^{\circ} \mathrm{C}$

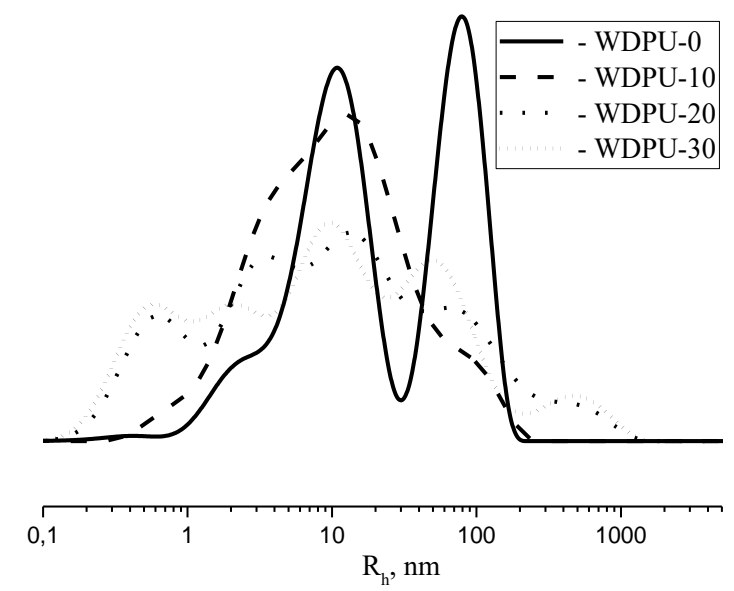

b) $\mathrm{T}=60^{\circ} \mathrm{C}$

Figure 2. Particles size distribution

The trend that is observed for WDPU-0 and WDPU-10 samples (Table 2) is worth mentioning, where a decrease in average hydrodynamic radius $\left(\mathrm{R}_{\mathrm{h}}{ }^{\mathrm{N}}\right)$ and the diminishing of particle size distribution (Fig. 2) with the increase in temperature can be seen. This observed pattern is apparently the result of aggregates destruction. It should be noted that distribution narrowing occurs due to the destruction of the aggregates of dispersion 
particles larger than $100 \mathrm{~nm}$. In contrast, the distribution broadens with increasing temperature for WDPU-20 and WDPU-30 samples. This may indicate their lower resistance to the temperature increase.

Table 2

\section{Hydrodynamic characteristics of WDPU}

\begin{tabular}{|c|c|c|}
\hline \multirow{2}{*}{ Sample } & \multicolumn{2}{|c|}{$\mathrm{R}_{\mathrm{h}}{ }^{\mathrm{N}}, \mathrm{nm}$} \\
\hline & $\mathrm{T}=25^{\circ} \mathrm{C}$ & $\mathrm{T}=60^{\circ} \mathrm{C}$ \\
\hline WDPU-0 & $\begin{array}{c}78.7 \\
(16,0 ; 201.2)^{*}\end{array}$ & $\begin{array}{c}38.9 \\
(9.6 ; 78.5)^{*}\end{array}$ \\
\hline WDPU-10 & 40.8 & 20.0 \\
\hline WDPU-20 & 20.4 & 49.1 \\
\hline WDPU-30 & 36.0 & 50.5 \\
\hline
\end{tabular}

It can be seen from the Table 2 that IPDI OIC-containing WDPU are characterized by a lower value of $\mathrm{R}_{\mathrm{h}}{ }^{\mathrm{N}}$ and by a narrower particle size distribution in comparison to WDPU-0 at room temperature. Thus we can conclude that IPDI OIC introduction (from $10 \mathrm{wt} \%$ to $30 \mathrm{wt} \% \%$ per pure IPDI) in to WDPU positively affects on their hydrodynamic characteristics.

The analysis of IPDI OIC content influence on WDPU thermo-mechanical properties using the DMA method was the next step.

Table 3 shows the transition temperatures measured by inflection points on dynamic elastic modulus ( $\left.E^{\prime}\right)$ vs. temperature graph and by maxima on dynamic loss modulus (E") vs. temperature graph. There are also elastic modulus values for sample temperature $30^{\circ} \mathrm{C}$ higher than glass transition temperature.

Table 3

Thermo-mechanical and thermal properties of WDPU

\begin{tabular}{|c|c|c|c|c|c|c|c|c|}
\hline \multirow{2}{*}{ Sample } & \multicolumn{9}{|c|}{$\mathrm{DMA}$} & \multicolumn{2}{c|}{$\mathrm{DSC}$} \\
\cline { 2 - 9 } & $\begin{array}{c}\mathrm{E}^{\prime}{ }_{\mathrm{Tg}+30}{ }^{\circ} \mathrm{C}, \\
\mathrm{MPa}\end{array}$ & $\begin{array}{c}\mathrm{T}_{1},{ }^{\circ} \mathrm{C} \\
\left(\mathrm{by} \mathrm{E}^{\prime \prime}\right)\end{array}$ & $\begin{array}{c}\mathrm{T}_{2},{ }^{\circ} \mathrm{C} \\
\left(\mathrm{by} \mathrm{E}^{\prime \prime}\right)\end{array}$ & $\begin{array}{c}\mathrm{T}_{3},{ }^{\circ} \mathrm{C} \\
\left(\mathrm{by} \mathrm{E}^{\prime}\right)\end{array}$ & $\begin{array}{c}\mathrm{T}_{4},{ }^{\circ} \mathrm{C} \\
(\text { by E') }\end{array}$ & $\mathrm{T}_{\mathrm{g}},{ }^{\circ} \mathrm{C}$ & $\mathrm{T}_{\mathrm{m}}$ & $\Delta \mathrm{H}_{\mathrm{m}}, \mathrm{kJ} / \mathrm{g}$ \\
\hline WDPU-0 & 1194 & -148 & -56 & 37 & 115 & -52 & 119 & -22.6 \\
\hline WDPU-10 & 1250 & -148 & -55 & 37 & 112 & -53 & 116 & -11.1 \\
\hline WDPU-20 & 1297 & -148 & -53 & 37 & 102 & -54 & 107 & -13.1 \\
\hline WDPU-30 & 1360 & -149 & -53 & 37 & 99 & -52 & 106 & -9.61 \\
\hline
\end{tabular}

It is well known from the kinetic theory of elasticity [26] that the molar mass of interstitial polymer chains is inversely proportional to the dynamic elastic modulus for sample temperature $30^{\circ} \mathrm{C}$ higher than glass tran-

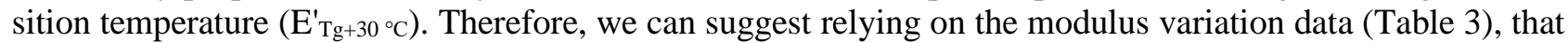
the molecular weight of polyurethane interstitial chains decreases when the IPDI OIC percentage in WDPU composition increases, with the assumption of constant density of WDPU-0 - WDPU-30 polymer samples. This is most likely due to the fact that, following its high branching and polarity, IPDI OIC enhances the polyurethane mesh formation possibility mainly by reason of hydrogen bonds.

All four samples revealed qualitatively equal results for temperature transitions. The first transition $\left(\mathrm{T}_{1}\right)$ is most likely a $\beta$-transition. The second peak on the loss modulus (E") vs. temperature graph resulted by the 'thawing' of polyester block segmental mobility. Thereby $T_{2}$ is the glass transition temperature $\left(\mathrm{T}_{\mathrm{g}}\right)$. It can be seen from the Table 3 that $\mathrm{T}_{\mathrm{g}}$ for studied polyurethanes there hardly depends on the IPDI OIC content. Temperature transitions $T_{3}$ and $T_{4}$ are most likely associated with initial melting of WDPU samples crystalline phase (first), as well as with their transition to a viscous flow state (second).

The nature of observed temperature transitions was confirmed by DSC analysis (Fig. 3, Table 3).

Degree of crystallinity is an important characteristic of polymer films. It can be estimated indirectly by melting enthalpy $\left(\Delta \mathrm{H}_{\mathrm{m}}\right)$ magnitude due to close chemical nature of prepared WDPU. So, Table 3 indicates more than double decrease in $\Delta \mathrm{H}_{\mathrm{m}}$ value with an increasing in IPDI OIC content in WDPU. The obtained experimental fact can be apparently explained by the branched structure of OIC, limiting the polyester block 'packing'. It should be expected that a further increase in IPDI OIC content in WDPU can lead to a completely amorphous polymer yielding. 


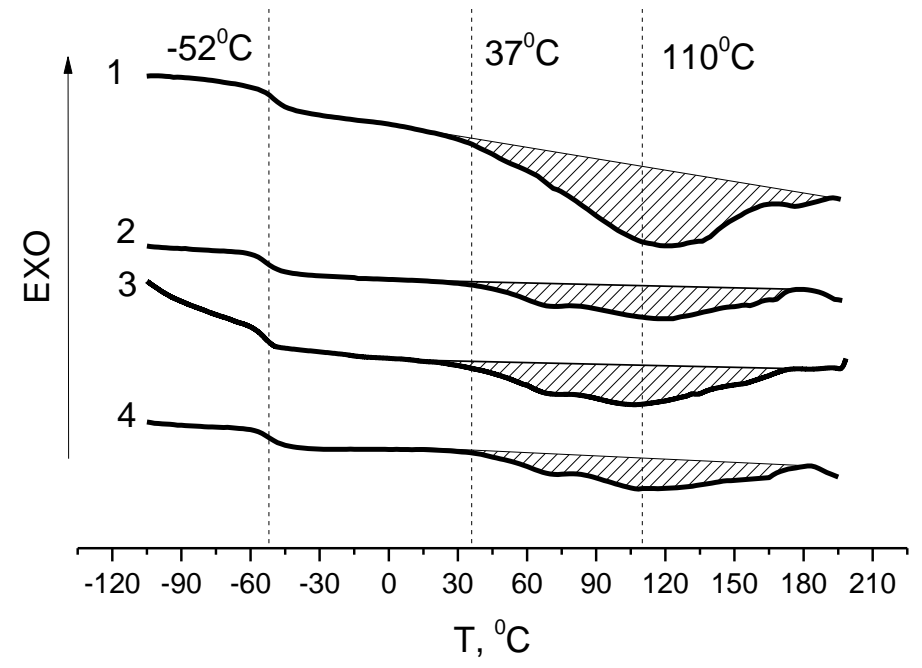

1 - WDPU-0; 2 - WDPU-10; 3 - WDPU-20; 4 - WDPU-30

Figure 3. DSC thermograms

\section{Conclusions}

We have investigated the effect of isophorone diisocyanate oligoisocyanurate content in water-dispersible polyurethane compositions on their hydrodynamic, thermo-mechanical, and thermal properties in this work. According to the obtained results it was found that the OIC introduction improves properties of both aqueous polyurethane dispersions and their polymer films. This is indicated, in particular, by decreasing of dispersed particle average size. Furthermore, isophorone diisocyanate oligoisocyanurates block the crystallization of coatings they involved in due to its branching. It will undoubtedly positively affect the performance of these coatings when used at reduced temperatures. Along with this, oligoisocyanurate introduction to water dispersible polyurethane compositions has no significant effect on decreasing of glass transition temperatures. It should provide high performance characteristics at low operating temperatures.

\section{Acknowledgments}

This work was performed in accordance with the state task, state registration No. AAAA-A19119041090087-4 using the equipment of the Multi-User Analytical Center of IPCP RAS.

We also wish to express our appreciation to Senior Research, Bubnova M.L., for performing DMA analysis and helping with results explanation.

\section{References}

1 Li A. Synthesis and characterization of water-borne diisocyanate crosslinkers from methyl ethyl ketoxime/2-methylimidazoleblocked aromatic isocyanates / A. Li, G. Fan, H. Chen, Q. Zhao // Research on Chemical Intermediates. — 2012. — Vol. 39, Iss. 8. P. 3565-3577. DOI:10.1007/s11164-012-0863-8

2 Wu Q. A High Strength Nanocomposite Based on Microcrystalline Cellulose and Polyurethane / Q. Wu, M. Henriksson, X. Liu, L. Berglund // Biomacromolecules. - 2007. — Vol. 8, Iss. 12. - P. 3687-3692. DOI:10.1021/bm701061t

3 Chernyayev D. Synthesis of Waterborne Polyurethanes Using the Isophorone Diisocyanate Oligoisocyanurates / D. Chernyayev, S. Karpov, A. Jalmuhanova, E. Badamshina // Key Engineering Materials. — 2019. — Vol. 816. - P. $323-327$. DOI:10.4028/www.scientific.net/kem.816.323

4 Saeedi S. Facile preparation of biodegradable dual stimuli-responsive micelles from waterborne polyurethane for efficient intracellular drug delivery / S. Saeedi, I. Omrani, R. Bafkary, E. Sadeh, H. Shendi, M. Nabid // New Journal of Chemistry. - 2019. — Vol. 43. — P. 18534-18545. DOI:10.1039/c9nj03773j

5 Caddeo S. Newly-designed collagen/polyurethane bioartificial blend as coating on bioactive glass-ceramics for bone tissue engineering applications / S. Caddeo, M. Mattioli-Belmonte, C. Cassino, N. Barbani, M. Dicarlo, P. Gentile, F. Baino, S. Sartori, C. Vitale-Brovarone, G. Ciardelli // Materials Science and Engineering: C. - 2019. - Vol. 96. - P. $218-233$. DOI:10.1016/j.msec.2018.11.012

6 Zhang W. Preparation and properties of waterborne polyurethane modified by aminoethylaminopropyl polydimethylsiloxane for fluorine-free water repellents / W. Zhang, X. Zou, X. Liu, Z. Liang, Z. Ge, Y. Luo // Progress in Organic Coatings. — 2019. — in press. DOI:10.1016/j.porgcoat.2019.105407 
7 Hajializadeh S. Synthesis and characterization of multiwall carbon nanotube/waterborne polyurethane nanocomposites / S. Hajializadeh, M. Barikani, S. Bellah // Polymer International. — 2017. — Vol. 66, Iss. 7. — P. 1074-1083. DOI: 10.1002/pi.5362

8 Wang X. A new method for preparing low viscosity and high solid content waterborne polyurethane —Phase inversion research / X. Wang, Q. Li // Progress in Organic Coatings. — 2019. — Vol. 131. - P. 285-290. DOI: 10.1016/j.porgcoat.2019.02.001

9 Mirmohseni A. Self-healing waterborne polyurethane coating by $\mathrm{pH}-$ dependent triggered-release mechanism / A. Mirmohseni, M. Akbari, R. Najjar, M. Hosseini // Journal of Applied Polymer Science. - 2019. - Vol. 136, Iss. 8. — P. 47082. DOI: 10.1002/app.47082

10 Najjar R. Preparation and corrosion performance of healable waterborne polyurethane coatings containing isophorone diisocyanate loaded silica capsules / R. Najjar, M. Akbari, A. Mirmohseni, M. Hosseini // Journal of the Taiwan Institute of Chemical Engineers. — 2018. - Vol. 93. - P. 1-10. DOI: 10.1016/j.jtice.2018.05.021

11 Paul F. Palladium(0)-Catalyzed Trimerization of Arylisocyanates into 1,3,5-Triarylisocyanurates in the Presence of Diimines: A Nonintuitive Mechanism / F. Paul, S. Moulin, O. Piechaczyk, P. Le Floch, J. Osborn // Journal of the American Chemical Society. — 2007. - Vol. 129, Iss. 23. - P. 7294-7304. DOI: 10.1021/ja068291k

$12 \mathrm{Nambu}$ Y. Synthesis of novel aromatic isocyanurates by the fluoride-catalyzed selective trimerization of isocyanates / Y. Nambu, T. Endo // The Journal of Organic Chemistry. - 1993. - Vol. 58, Iss. 7. - P. 1932-1934. DOI: 10.1021/jo00059a055

13 Huybrechts J. 2.1 VOC solvent borne 2K clear coats based on star oligoethers / J. Huybrechts, L. Tanghe // Progress in Organic Coatings. - 2007. - Vol. 58, Iss. 2-3. - P. 217-226. DOI: 10.1016/j.porgcoat.2006.09.029

14 Jamdar V. Depolymerization Study of PET Waste Using Aminoethylethanolamine and Recycled Product Application as Polyesteramide Synthesis / V. Jamdar, M. Kathalewar, A. Sabnis // Journal of Polymers and the Environment. — 2017. - Vol. 26 , Iss. 6. - P. 2601-2618. DOI: 10.1007/s10924-017-1149-4

15 Burel F. The influence of isocyanurate content on the bioperformance of hydrocarbon-based polyurethanes / F. Burel, L. Poussard, M. Tabrizian, Y. Mehri, C. Bunel // Journal of Biomaterials Science, Polymer Edition. — 2008. — Vol. 19, Iss. 4. - P. 525540. DOI: $10.1163 / 156856208783719518$

16 Zhengjian Q. Synthesis, Characterization of a Novel Light Stable Cross-Linker - Isophorone Diisocyanate Terpolymer Composite / Q. Zhengjian, L. Xiangxin, S. Yueming, L. Zhenyang // Polymer-Plastics Technology and Engineering. — 2006. - Vol. 45, Iss. 8. - P. 953-956. DOI: 10.1080/03602550600723357

17 Шмитц И. Алифатические полиизоцианаты для современных полиуретановых лакокрасочных материалов / И. Шмитц, Х. Мундшток, А. Борисов, А. Сырейщиков, М. Буланов, Л. Филипс и др. // Лакокрасочные материалы и их применение. 2006. - № 8. - C. 3-6.

18 Guo L. Synthesis and properties of novel water-dispersible polyisocyanates / L. Guo, L. Wang, S. Huang, J. Qu // Journal of Applied Polymer Science. — 2017. — Vol. 134, Iss. 17. - P. 44735. DOI: 10.1002/app.44735

19 Claudio-Rizo J. Improved properties of composite collagen hydrogels: protected oligourethanes and silica particles as modulators / J. Claudio-Rizo, M. Rangel-Argote, P. Muñoz-González, L. Castellano, J. Delgado, G. Gonzalez-García et al. // Journal of Materials Chemistry B. - 2016. - Vol. 4, Iss.40. - P. 6497-6509. DOI: 10.1039/c6tb01673a

20 Lim C. Surface modification with waterborne fluorinated anionic polyurethane dispersions / C. Lim, H. Choi, S. Noh // Journal of Applied Polymer Science. — 2002. — Vol. 86, Iss.13. - P. 3322-3330. DOI: 10.1002/app.11274

21 Karpov S. Kinetics of urethane formation from isophorone diisocyanate: The alcohol nature effect / S. Karpov, V. Lodygina, V. Komratova, A. Dzhalmukhanova, G. Malkov, E. Badamshina // Kinetics and Catalysis. — 2016. — Vol. 57, Iss. 3. - P. $319-325$. DOI: $10.1134 / \mathrm{s} 0023158416030058$

22 Karpov S. Kinetics of urethane formation from isophorone diisocyanate: The catalyst and solvent effects / S. Karpov, V. Lodygina, V. Komratova, A. Dzhalmukhanova, G. Malkov, E. Badamshina // Kinetics and Catalysis. — 2016. — Vol. 57 , Iss. 4. - P. 422-428. DOI: $10.1134 / \mathrm{s} 0023158416040066$

23 Weissberger A. Organic Solvents: Physical Properties and Methods of Application // A. Weissberger, E. Proskauer, J. Riddick, E. Toops. - New York, USA: Interscience, 1955.

24 Dzalmukhanova A. IR spectroscopy method for determining the reactivity of isocyanate groups in isophorone diisocyanate reactions / A. Dzalmukhanova, V. Lodygina, V. Komratova, S. Karpov, E. Badamshina // Journal of Applied Spectroscopy. - 2015. — Vol. 82, Is. 1. - P. 145-148. DOI: 10.1007/s10812-015-0077-0

25 ASTM International. Standard Test Method for Isocyanate Groups in Urethane Materials or Prepolymers. West Conshohocken, PA: ASTM International, 1997.

26 Tobolsky A. Properties and Structure of Polymers / A. Tobolsky. — New York, USA: Wiley, 1960.

\author{
С.В. Карпов, А.С. Джалмуханова, Д.А. Черняев, В.П. Лодыгина, \\ В.В. Комратова, Г.В. Малков, Э.Р. Бадамшина
}

\title{
Изофорондиизоцианат олигоизоцианураттарының судисперсиялық полиуретандардың қасиеттеріне әсерін зерттеу
}

\begin{abstract}
Олигоизоцианураттар (ОИЦ) - түрлі диизоцианаттарды циклотримеризациялау реакциясы, функционалдылығы үштен көп (әлеуетті байланыстырушы агенттер). Олар химиялық полимерлік өнеркәсіпте түрлі қасиеттері бар полиуретанды жабындарды алу үшін диизоцианаттарға қоспа ретінде, сондай-ақ тікелей полиуретандар синтезіне арналған изоцианаты бар компонент ретінде қолданыс тапты. ОИЦ негізінде синтезделген полимерлер бірқатар бірегей қасиеттерге ие, атап айтқанда, жоғары термо-отқа, сондай-ақ, УК-сәулеленуге және гидролизге төзімді. Мақалада алынған өнімдердің гидродинамикалық,
\end{abstract}


термомеханикалық және жылу физикалық қасиеттеріне судисперсиялық полиуретандар құрамындағы изофорондиизоцианат (ИФДИ ОИЦ) олигоизоцианурат құрамының әсері зерттелген. Осы мақсатта ацетондық әдіспен изофорондиизоцианат (ИФДИ), полибутиленадипинат (ПБА) және еркін ИФДИ салыстырмалы түрде 10-30 \% салмақ ОИЦ ИФДИ, полибутиленадипинат (ПБА) және 2,2-бис(гидроксиметил)пропион қышқылы (ДМПА) негізіндегі судисперсиялық полиуретандардың үлгілері синтезделді. NCO-ифди ОИЦ тобының ВДПУ синтезі кезінде тігілген құрылымдардың пайда болуын болдырмау үшін морфолинмен қоршалған. Алынған дисперсиялар мен олардың негізіндегі жабындар динамикалық механикалық талдау (ДМА), дифференциалды сканерлеу калориметрия (ДСК) және жарықтың динамикалық шашырауы (ДРС) әдістерін пайдалана отырып сипатталған. Олигоизоцианураттар полиуретандардың су дисперсияларының, сондай-ақ олардың негізіндегі полимерлік пленкалардың сипаттамаларын жақсартатыны анықталды. Сонымен қатар, олигоизоцианураттар олардың негізіндегі жабындардың кристалдануына кедергі келтіреді, бұл олардың пайдалану сипаттамаларына оң әсер етеді.

Кілт сөздер: полиуретан, полиуретандардың су дисперсиясы, изофорондиизоцианат, 2,2-бис(гидроксиметил)пропион қышқылы, полибутиленадипинат, олигоизоцианурат изофорондиизоцианата, динамикалық жарық шашырауы, динамикалық механикалық талдау.

\author{
С.В. Карпов, А.С. Джалмуханова, Д.А. Черняев, В.П. Лодыгина, \\ В.В. Комратова, Г.В. Малков, Э.Р. Бадамшина
}

\title{
Исследование влияния олигоизоциануратов изофорондиизоцианата на свойства вододисперсионных полиуретанов
}

\begin{abstract}
Олигоизоцианураты (ОИЦ) - продукты реакции циклотримеризации различных диизоцианатов с функциональностью больше трех (потенциальные сшивающие агенты). Они нашли применение в химической полимерной промышленности в качестве добавки к диизоцианатам для получения полиуретановых покрытий с различными свойствами, а также непосредственно в качестве изоцианатсодержащего компонента для синтеза полиуретанов. Полимеры, синтезированные на основе ОИЦ, обладают рядом уникальных свойств, а именно: повышенной термо-, огнестойкостью, а также устойчивостью к УФ-излучению и гидролизу. В статье исследовано влияние содержание олигоизоциануратов изофорондиизоцианата (ОИЦ ИФДИ) в составе вододисперсионных полиуретанов на гидродинамические, термомеханические и теплофизические свойства получаемых продуктов. С этой целью ацетоновым методом были синтезированы образцы вододисперсионных полиуретанов на основе изофорондиизоцианата (ИФДИ), полибутиленадипината (ПБА) и 2,2-бис(гидроксиметил)пропионовой кислоты (ДМПА), содержащие 10-30 \% весовых ОИЦ ИФДИ относительно свободного ИФДИ. Для исключения образования сшитых структур при синтезе ВДПУ NCO-группы ОИЦ ИФДИ частично блокировали морфолином. Полученные дисперсии и покрытия на их основе были охарактеризованы с использованием методов динамического механического анализа (ДМА), дифференциальной сканирующей калориметрии (ДСК) и динамического рассеяния света (ДРС). Установлено, что олигоизоцианураты улучшают характеристики как водных дисперсий полиуретанов, так и полимерных пленок на их основе. Кроме того, ввиду своей разветвленности, олигоизоцианураты препятствуют кристаллизации покрытий на их основе, что, несомненно, положительно скажется на их эксплуатационных характеристиках.
\end{abstract}

Ключевые слова: полиуретан, водная дисперсия полиуретанов, изофорондиизоцианат, 2,2-бис(гидроксиметил)пропионовая кислота, полибутиленадипинат, олигоизоцианурат изофорондиизоцианата, динамическое светорассеяние, динамический механический анализ.

\section{References}

1 Li, A., Fan, G., Chen, H., \& Zhao, Q. (2012). Synthesis and characterization of water-borne diisocyanate crosslinkers from methyl ethyl ketoxime/2-methylimidazole-blocked aromatic isocyanates. Research on Chemical Intermediates, 39(8), 3565-3577. DOI: $10.1007 / \mathrm{s} 11164-012-0863-8$

2 Wu, Q., Henriksson, M., Liu, X., \& Berglund, L.A. (2007). A High Strength Nanocomposite Based on Microcrystalline Cellulose and Polyurethane. Biomacromolecules, 8(12), 3687-3692. DOI: 10.1021/bm701061t

3 Chernyayev, D.A., Karpov, S.V., Jalmuhanova, A.S., \& Badamshina, E.R. (2019). Synthesis of Waterborne Polyurethanes Using the Isophorone Diisocyanate Oligoisocyanurates. Key Engineering Materials, 816, 323-327. DOI: 10.4028/www.scientific.net/kem.816.323

4 Saeedi, S., Omrani, I., Bafkary, R., Sadeh, E., Shendi, H. K., \& Nabid, M.R. (2019). Facile preparation of biodegradable dual stimuli-responsive micelles from waterborne polyurethane for efficient intracellular drug delivery. New Journal of Chemistry, 43, 18534-18545. DOI: 10.1039/c9nj03773j

5 Caddeo, S., Mattioli-Belmonte, M., Cassino, C., Barbani, N., Dicarlo, M., \& Gentile, P., et al. (2018). Newly-designed collagen/polyurethane bioartificial blend as coating on bioactive glass-ceramics for bone tissue engineering applications. Materials Science and Engineering: C., 96, 218-233. DOI: 10.1016/j.msec.2018.11.012 
6 Zhang, W., Zou, X., Liu, X., Liang, Z., Ge, Z., \& Luo, Y. (2019). Preparation and properties of waterborne polyurethane modified by aminoethylaminopropyl polydimethylsiloxane for fluorine-free water repellents. Progress in Organic Coatings, 105407. DOI: 10.1016/j.porgcoat.2019.105407

7 Hajializadeh, S., Barikani, M., \& Bellah, S.M. (2017). Synthesis and characterization of multiwall carbon nanotube/waterborne polyurethane nanocomposites. Polymer International, 66(7), 1074-1083. DOI: 10.1002/pi.5362

8 Wang, X., \& Li, Q. (2019). A new method for preparing low viscosity and high solid content waterborne polyurethane — Phase inversion research. Progress in Organic Coatings, 131, 285-290. DOI: 10.1016/j.porgcoat.2019.02.001

9 Mirmohseni, A., Akbari, M., Najjar, R., \& Hosseini, M. (2018). Self-healing waterborne polyurethane coating by pH-dependent triggered-release mechanism. Journal of Applied Polymer Science, 47082. DOI: 10.1002/app.47082

10 Najjar, R., Akbari, M., Mirmohseni, A., \& Hosseini, M. (2018). Preparation and corrosion performance of healable waterborne polyurethane coatings containing isophorone diisocyanate loaded silica capsules. Journal of the Taiwan Institute of Chemical Engineers, 93, 1-10. DOI: 10.1016/j.jtice.2018.05.021

11 Paul, F., Moulin, S., Piechaczyk, O., Le Floch, P., \& Osborn, J.A. (2007). Palladium(0)-Catalyzed Trimerization of Arylisocyanates into 1,3,5-Triarylisocyanurates in the Presence of Diimines: A Nonintuitive Mechanism. Journal of the American Chemical Society, 129(23), 7294-7304. DOI: 10.1021/ja068291k

12 Nambu, Y., \& Endo, T. (1993). Synthesis of novel aromatic isocyanurates by the fluoride-catalyzed selective trimerization of isocyanates. The Journal of Organic Chemistry, 58(7), 1932-1934. DOI: 10.1021/jo00059a055

13 Huybrechts, J.T., \& Tanghe, L.M. (2007). 2.1 VOC solvent borne 2K clear coats based on star oligoethers. Progress in Organic Coatings, 58(2-3), 217-226. DOI: 10.1016/j.porgcoat.2006.09.029

14 Jamdar, V., Kathalewar, M., \& Sabnis, A. (2017). Depolymerization Study of PET Waste Using Aminoethylethanolamine and Recycled Product Application as Polyesteramide Synthesis. Journal of Polymers and the Environment, 26(6), 2601-2618. DOI: 10.1007/s10924-017-1149-4

15 Burel, F., Poussard, L., Tabrizian, M., Merhi, Y., \& Bunel, C. (2008). The influence of isocyanurate content on the bioperformance of hydrocarbon-based polyurethanes. Journal of Biomaterials Science, Polymer Edition, 19(4), 525-540. DOI: $10.1163 / 156856208783719518$

16 Zhengjian, Q., Xiangxin, L., Yueming, S., \& Zhenyang, L. (2006). Synthesis, Characterization of a Novel Light Stable CrossLinker - Isophorone Diisocyanate Terpolymer Composite. Polymer-Plastics Technology and Engineering, 45(8), 953-956. DOI: $10.1080 / 03602550600723357$

17 Shmitts, J., Mundshtok, H., Borisov, A., Syreishchikov, A., Bulanov, M., \& Filips, L. et al. (2006). Alifaticheskie poliizotsianaty dlia sovremennykh poliuretanovykh lakokrasochnykh materialov [Aliphatic polyisocyanates for modern polyurethane paints and varnishes]. Lakokrasochnye materialy i ikh primenenie - Russian Coatings Journal, 8, 3-6 [in Russian].

18 Guo, L., Wang, L., Huang, S., \& Qu, J. (2017). Synthesis and properties of novel water-dispersible polyisocyanates. Journal of Applied Polymer Science, 134(17), 44735. DOI: 10.1002/app.44735

19 Claudio-Rizo, J.A., Rangel-Argote, M., Muñoz-González, P.U., Castellano, L. E., Delgado, J., \& Gonzalez-García, G. et al. (2016). Improved properties of composite collagen hydrogels: protected oligourethanes and silica particles as modulators. Journal of Materials Chemistry B, 4(40), 6497-6509. DOI: 10.1039/c6tb01673a

20 Lim, C. H., Choi, H.S., \& Noh, S.T. (2002). Surface modification with waterborne fluorinated anionic polyurethane dispersions. Journal of Applied Polymer Science, 86(13), 3322-3330. DOI:10.1002/app.11274

21 Karpov, S.V., Lodygina, V.P., Komratova, V.V., Dzhalmukhanova, A.S., Malkov, G.V., \& Badamshina, E.R. (2016). Kinetics of urethane formation from isophorone diisocyanate: The alcohol nature effect. Kinetics and Catalysis, 57(3), 319-325. DOI: $10.1134 / \mathrm{s} 0023158416030058$

22 Karpov, S.V., Lodygina, V.P., Komratova, V.V., Dzhalmukhanova, A.S., Malkov, G.V., \& Badamshina, E.R. (2016). Kinetics of urethane formation from isophorone diisocyanate: The catalyst and solvent effects. Kinetics and Catalysis, 57(4), 422-428. DOI: $10.1134 / \mathrm{s} 0023158416040066$

23 Weissberger, A., Proskauer, E.S., Riddick, J. A., \& Toops, E. E. (1955). Organic Solvents: Physical Properties and Methods of Application. New York, USA: Interscience.

24 Dzhalmukhanova, A.S., Lodygina, V.P., Komratova, V.V., Karpov, S.V., Malkov, G.V., \& Badamshina, E.R. (2015). IR spectroscopy method for determining the reactivity of isocyanate groups in isophorone diisocyanate reactions. Journal of Applied Spectroscopy, 82(1), 145-148. DOI: 10.1007/s10812-015-0077-0

25 ASTM International. (1997). Standard Test Method for Isocyanate Groups in Urethane Materials or Prepolymers. West Conshohocken, PA: ASTM International.

26 Tobolsky, A. (1960). Properties and Structure of Polymers. New York, USA: Wiley. 